\title{
Hybrid Identities: John Henry Mackay and Houston Stuart Chamberlain between Englishness and Germanness
}

\begin{abstract}
The son of a Scottish marine insurance broker and a German mother, John Henry Mackay (6 February 1864-16 May 1933) was born in Greenock, Scotland. He was only nineteen months old when his father died. His mother returned with him to Germany, where he grew up with German as his mother tongue. An allowance provided by his mother gave Mackay financial independence after completing his schooling. He travelled much, and chose the career of a writer, at first of lyric and narrative poetry. He made translations from poetic and political English texts, but never wrote that language well. Research on Mackay concentrates mostly on two facets of his writings: the political texts, such as Die Anarchisten: Kulturgemälde aus dem Ende des XIX. Jahrhunderts [The Anarchists: A Picture of Civilization at the Close of the Nineteenth Century] (1891), and the homoerotic/ pederastic narratives (Die Bücher der namenlosen Liebe [Books of the Nameless Love] (1905-1913) published under the pseudonym of Sagitta. The approach in this article focuses on different aspects of his poetics and work, specifically on how he draws on multilingualism and cultural hybridity, but also on his literary creativity compared to Houston Stewart Chamberlain's work. In contrast to Chamberlain's writings, Mackay's otherness turned into a creative force and became a dominant theme in his poetry, narratives, and novels.
\end{abstract}

Keywords: cultural hybridity, Houston Stewart Chamberlain, identity, John Henry Mackay, literary strategies

\section{The Führer durch die Moderne Literatur}

At the beginning of the twentieth century, two "Englishmen" who wrote in German were considered among the most prominent contemporary authors and integrated into the canon of modern literature by the Führer durch die Moderne Literatur [Guide to Modern Literature]. ${ }^{1}$ Hanns Heinz Ewers (1871-1943), who was a German actor,

1 By 1911, Ewers's Führer durch die Moderne Literatur [1906] had sold 15,000 copies, and a new, revised edition was published (1911). The three hundred entries remained but were updated.

Ә Open Access. (C) 2020 Gerald Bär, published by De Gruyter. (c) BY-NC-ND This work is licensed under a Creative Commons Attribution-NonCommercial-NoDerivatives 4.0 License. 
film theorist, poet, philosopher, translator, and writer of short stories and novels, founded this lexicon of modern writers. The Führer durch die Moderne Literatur connects the authors Houston Stewart Chamberlain and John Henry Mackay through their publications in the German language: in the 1911 edition, Ewers characterizes Chamberlain as follows (the variant in square brackets refers to the text of the first edition of 1906): "Houston Stewart Chamberlain, geb. 1855 in Portsmouth, lebt in Bayreuth [Wien]. Chamberlain schreibt, obwohl englischer Abstammung, wie der Schotte John Henry Mackay, in deutscher Sprache und machte sich zuerst durch seine ausgezeichneten Schriften über Richard Wagner bekannt” (Ewers 1911, 36). The introductory words by Ewers's collaborator Erich Mühsam for the entry on Mackay are (variant first-edition text in square brackets): “John Henry Mackay, geb. $1864 \mathrm{zu}$ Greenock [Greenoch] in Schottland. Mackay vertritt in Prosa und Dichtung die individualistisch-anarchistische Richtung. Er [Mackay] schreibt, obwohl ein geborener Schotte, nur deutsch, ähnlich wie es sein Landsmann Houston Stewart Chamberlain und manche skandinavischen Schriftsteller tun” (Ewers 1911, 118).

In this case, the widespread tendency of not fully distinguishing between England and Scotland is accompanied by an important lack of information, as Mackay had become a German citizen at the turn of the century, after he decided to live in Berlin for a longer period of time. ${ }^{2}$ Chamberlain grew up bilingually in France, but felt homeless when he was sent to school in England. In 1870, he settled in the Germany of Bismarck and Wilhelm II, which he soon began to idealize. In a letter to his aunt from Seville, dated 23 May 1876, he affirms his growing "Verehrung" and "leidenschaftliche Liebe" for Germany and his belief that "die ganze Zukunft Europas - d.h. der Zivilisation der Welt - Deutschland in den Händen liegt” (Chamberlain 1919, 59).

Ewers, who would join the NSDAP in 1931, praises Chamberlain in his lexicon of modern authors for defending the racial viewpoint ("Rassenstandpunkt") in his best-seller Die Grundlagen des neunzehnten Jahrhunderts [The Foundations of the Nineteenth Century] (1899) ${ }^{3}$ and announcing the hegemony of the German race. This dubious approach is criticised as unfounded and even anti-scientific by other contemporary authors. According to Friedrich Hertz's critical study of race and culture, theories of race along the lines introduced by Gobineau's Essai sur l'inégalité des races humaines [Essay on the Inequality of the Human Races] (18531855) and Chamberlain, scientifically untenable as they were, are still running rampant in contemporary general opinion and attitudes (Hertz 1915, vi). His ana-

2 See Dobe (1987, 39).

3 Chamberlain's Die Grundlagen des neunzehnten Jahrhunderts was translated into English as The Foundations of the Nineteenth Century by John Lees (1911). 
lysis of their theories proves convincingly that they are based on a lack of knowledge and wrong assumptions (Hertz 1915, 131-156). Discarding Chamberlain's approach as an “Attentat auf das gesunde Denken unserer Zeit” (Hertz 1915, 156), he warns of their seductive potential, especially in Germany. ${ }^{4}$

In Chamberlain's essay “Die deutsche Sprache” (1914), Leo Spitzer noticed a blending of the concepts of language and race: "das Deutsche soll rein und ungemischt, stetig und ununterbrochen auf die Urzeit zurückgehen, während das Französische aus einem Kompromiß zwischen zwei widerstrebenden Sprachen entstanden sei” (Spitzer 1918, 24). Refuting Chamberlain's claims in a profound linguistic analysis, Spitzer also observes the former's contempt for England and the English language:

Und auf so schwacher Grundlage baut Chamberlain den angeblich logischen Schluß: "daher nun die zwingende Notwendigkeit, daß die deutsche Sprache - nicht die englische - die Weltsprache wird.” (Deutsche Sprache S. 32) Aber er verrät gleich in den nächsten Sätzen, daß der Abscheu vor England ihn gegen das Englische einnimmt. (Spitzer 1918, 29).

Spitzer points out psychological factors that determine the general interest in Chamberlain's attempt to prove the superiority of the German language on racial terms. ${ }^{5}$ General hostility to the enemy's culture and language in times of war and the assumption that language can expose the collective "innerstes Seelenleben" (Spitzer 1918, 32) reveal the conceptual conflict between "civilization" and "culture" which Norbert Elias would later analyse in his seminal work Über den Prozeß der Zivilisation (1939).

While Chamberlain paved the way for Nazi ideology, several of Mackay's publications were of the kind that ran the risk of being burnt or branded "entartet" during the Fascist regime: the political texts, such as Die Anarchisten [The Anarchists] (1891, translated into English the same year) ${ }^{6}$ and the homoerotic/pederast narratives Die Bücher der namenlosen Liebe [Books of the Nameless Love] (19051913) that he published under the pseudonym of Sagitta. Nevertheless, Die Anarchisten had sold 6,500 copies in Germany by 1903, 8,000 by 1911, and over

4 "Ein Franzose und ein Engländer, Gobineau und Chamberlain, sind die Propheten des heutigen Rassenglaubens. In ihrer Heimat fanden sie keine Beachtung, dafür erwuchs ihnen in Deutschland eine begeisterte Jüngerschaft” (Hertz 1915, 131).

5 "Im ganzen ist also bei Chamberlain zu bemerken, daß er Sprache und Rasse zwar nicht identifiziert, aber stets die an der einen gemachten Erfahrungen auf die andere überträgt: die Deutschen erscheinen ihm als das auserwählte Volk, daher soll die deutsche Sprache siegreich sein. Und die deutsche Sprache ist vortrefflich weil es die deutsche Rasse ist” (Spitzer 1918, 30). 6 Translated from the German by George Schumm and published by Benjamin R. Tucker, Boston, 1891. 
15,000 by the time of the author's death on 16 May 1933, ten days after the Nazi book burnings at the Institut für Sexualwissenschaft. However, my approach will focus on other aspects in his work: from language contact and literary creativity, to travel and translation, to the translingual borrowing of literary, aesthetic, and rhetorical structures and strategies. These factors influence Mackay's hybrid identity and his coming to terms with concepts of Germanness and Englishness.

\section{The search for identity in John Henry Mackay's early writings}

Mackay was only nineteen months old when his father, John Farquhar Mackay, a marine insurance broker, died. Soon afterwards, his mother, Louise Auguste Mackay, née Ehlers, returned with him to Germany, where he grew up with German as his mother tongue. Unlike Chamberlain, whose Prussian teacher Otto Kuntze was a determining factor in his adoration for German language and culture, ${ }^{7}$ Mackay disliked his Prussian stepfather, his stepbrother, and the education that he received at school. However, this strong aversion, which is expressed in poems such as "Moderne Jugend" [Modern Youth] (1886), did not influence his linguistic preference. After his unhappy schoolyears as a boarder, he worked briefly for an editor and studied sporadically for five semesters at three different universities (Kiel, Leipzig, Berlin). He decided to live in Berlin, where he came into contact with literature, namely with its latest, its most naturalistic, and its more or less vocal representatives: “Ich kam [...] in Fühlung mit der 'Literatur', der allerjüngsten, der naturalistischen, und ihrer mehr oder minder lauten Vertreter. Es waren alle Genies. Ich fühlte mich nicht zugehörig und ging nach London” (Mackay 1978, 33). Later, two of these representatives of literary naturalism, namely Arno Holz and Hermann Bahr, would remember Mackay as a fashionable anarchist. ${ }^{8}$

7 Chamberlain (1919, 56-59).

8 In Der Antisemitismus: Ein internationales Interview, Hermann Bahr gives a short account of meeting Mackay in Paris: "Er hat seinen wilden Drang zur Freiheit mit Fleiß gezüchtet und in ein System gebracht, bis aus dem philosophischen Sänger der starre Dogmatiker des Anarchismus wurde, der größte vielleicht, gewiß der ehrlichste, den Europa heute hat” (1894, 93-94). Arno Holz would parody the loner as Frederick S. Bellermann in his satirical "Berlin-Comedy" Socialaristokraten: a "Deutsch dichtender Amerikaner, Anfang Dreißig" $(1896,3)$ and "Beginnender Fettansatz. Ganz kleine Koteletts, Glatze. Das übrige blond. In jeder Beziehung durchaus korrekt! Beim Sprechen sich überstürzend. Stößt ein klein wenig mit der T-zunge an. Kleidung letzte englische Mode, aber nicht übertrieben” $(1896,7)$. 
In 1885, after visiting Scottish relatives, John Henry Mackay published his first book: Kinder des Hochlands [Children of the Highlands], a narrative poem set on the Isle of Mull, which lies a considerable distance from his town of birth. In the characters of his poem, he included authentic references to socially disadvantaged local people - a feature of literary naturalism. There was, for example, one Duncan MacTavish, a fisherman, born in 1821, whose first wife was called Catherine (not Sheila, as in the poem) McPhail. ${ }^{9}$ One Thomas Goldie of Mull, in the poem of Irish origin but appropriating Scottish attire ("Schottlands Tracht"; Mackay 1911, 3: 39), was born around 1812. ${ }^{10}$ These people lived at the time when Mackay was born and their stories were being told. However, those stories do not match the narrative of Kinder des Hochlands.

Mackay chose a programmatic introduction to his poem, invoking and quoting the authority of Sir Walter Scott, of whom he begs forgiveness for using the Harp of the North ("Harfe des Nordens"; 1911, 3: [9]):

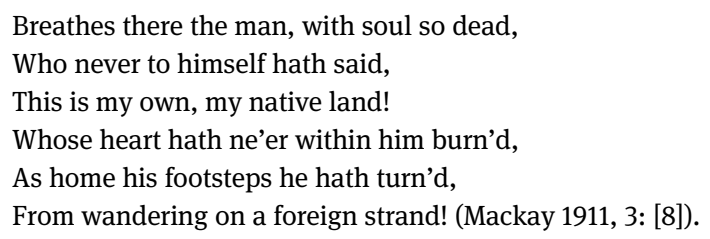

With these lines from The Lay of the Last Minstrel (Scott 1805, 4.1) Mackay, estranged in the German environment, certainly expresses his wish to go back to his roots. Echoing Goethe's Iphigenie auf Tauris, he went searching with his soul for the land of the Scots, exchanging Homer and Euripides for Ossian and Walter Scott. Indeed, there are Ossianic reminiscences in Mackay's epic poem: the mossy stone ("moosigen Stein"; 1911, 3: 29) and the passage at the beginning of the fifth song (1911, 3: 60) which reminds us of the address to the moon in "Darthula" ([Macpherson] 1765, 218-220).

Mackay ironically justified the inclusion of this first poetic attempt in the preface to the 1911 edition of his collected works with the assurance of "vertrauenswürdige Stimmen" (1911, 1: [11]) that it was his only book to be placed without hesitation even into the hands of young girls. Undeniably, the book that would make him famous was considered far more dangerous, bearing in

9 Together with Angus McPhail, possibly a brother of Duncan's first wife Catherine, Duncan MacTavish appeared before Sheriff Substitute Robertson on 30 June 1860. See "Maritime Monday" (2012).

10 See "ThomasGOLDIE" n.d. 
mind the threat of Bismarck's Anti-Socialist Laws (Sozialistengesetze) which had been passed in 1878 by the German Reichstag. Mackay's groundbreaking "cultural painting” Die Anarchisten: Kulturgemälde aus dem Ende des XIX. Jahrhunderts [The Anarchists: A Picture of Civilization at the Close of the Nineteenth Century] appeared in 1891 in Zurich, nearly a decade before Chamberlain's Die Grundlagen des neunzehnten Jahrhunderts. It portrays the London of exiles in the autumn of 1887, when the author came into close contact with several protagonists of the social movement. Ritchie $(1980,1988)$ points out that the French protagonist Carrard Auban, or rather "Mackay-Auban," does not concentrate exclusively on the lives of the German exiles, as his thoughts and reflections express a great affection for London (Ritchie 1988, 638, 639). Everything attracts his attention in the "Heart of the World-Metropolis" (title of the first chapter of The Anarchists): from the copies of a new German paper, the Londoner Freie Presse, to "sexual life - here wildly riotous" (Mackay 1891, 17). The novel is an account of impressions gained during extensive walks from the East to the West End and from the Docklands to Buckingham Palace. According to the restless narrator figure, one either loves London or hates it. This observant flâneur from Paris never mentions Scotland, but claims that the English capital had shown him too much - much more than it does to the inhabitant and the visitor - and now he wished to see it all. With the vision of hindsight, Mackay confirms the blending of autobiographical fact and fiction: "Ich ging nach London, und hier, in London war es, wo sich die große Umwandlung in meinem Sehen und Denken vollzog, welche meinem Leben seine Richtung und meiner Arbeit ihren Sinn geben sollte: die ungeheure Bewegung, die sich die soziale nennt, erfaßte auch mich und riß mich in ihren Strudel” (Mackay 1978, 34). Apart from these seemingly modernist new perceptions, Mackay made contact with Algernon Charles Swinburne, declaring: "London - dein unvergeßliches Jahr, das mir mein Buch gab! - Mehr als das: das mich mir gab!” (Mackay 1978, 34).

And yet, the process of finding himself in a British environment, as a stranger and possibly better adapted to it than most German exiles, could not continue in the same circumstances back in Berlin. Aware of cultural interferences, Mackay felt isolated but accepted it as the price he had to pay for his freedom: "Splendid Isolation! - Wie anders hätte ich leben und arbeiten können, als in dir! -” (Mackay 1978, 48). His work consisted of the production of literature, a naturalistic prose of which he claimed to be the founder in Germany. His narratives "Schatten" [Shadows] (1887), as well as "Existenzen" [Existences] and "Nur eine Kellnerin" [Only a Waitress] in Moderne Stoffe [Modern Material] (1888), were indeed published before Papa Hamlet (1889) by Schlaf and Holz, but less influential as literary trendsetters. Mackay did not even include "Schatten" in 
his collected works of 1911. However, in the beginning he wrote mainly poetry influenced by late romanticism, reflecting his situation between two cultures and his isolation: "Sind Gedichte geschrieben für andere? - Ist es nicht einzig eine Zwiesprache zwischen dir und deinem Selbst? - dir und der Natur? - dir und der Ewigkeit? - - Zwischen dir und deinem erträumten Wesen - Rufe der Sehnsucht, hinaus in eine stumme und unbekannte Ferne? - - -" (Mackay 1978, 92).

In Mackay's poem "Stimmungen” [Moods], this introspective dialogue turns into an expressive screaming:

Von Zeit zu Zeit, in nächtlich-dunklen Stunden,

Erklingt ein Schrei in mir, unheimlich-gellend,

Ein Ton, so scharf, wie wenn auf Marmorfliesen,

Ein Glas zerspringt, in Trümmer hin zerschellend. (Mackay 1911, 1: 29)

This piercing inner voice is also audible in "Eindringlinge" [Intruders]: "Die toten Schatten - tote, tote Zeit - / Und doch nicht tot - o wie es in mir schreit" (Mackay 1911, 1: 51). The origin of the phenomenon gains even more contours and is explained in "In der Verbannung" [In Banishment], after three rhetorical questions, "Was blickt dein Auge so übernächtig? / Was schweigt dein Mund? - Daß er nicht schreit?" (1911, 1: 127), and

Tagsüber versteckst du in einsamer Kammer

Dein niemals verstandenes, mißachtetes Leid,

Doch gellend durchschreit dein hilfloser Jammer

Bei Nacht die hallenden Gänge weit. (Mackay 1911, 1: 128)

Comparable with the voice in Edgar Allan Poe's "William Wilson" (1839) that becomes visible to the protagonist in the shape of his repressed second self, or doppelgänger, Mackay uses the Gothic environment (at night, echoing halls) to illustrate the tormenting effects of isolation and disregarded suffering. On the other hand, Mackay's poem "Erschütterung" [Shock] gives evidence that the inner voice is also a source for inspiration and creativity:

Es lauschte heut mein Ohr nach innen

Und bebte plötzlich -: es vernahm

Die Quelle nicht mehr hörbar rinnen,

Aus der bisher die Kraft mir kam. (Mackay 1911, 1: 220)

The disconcerting silence of the inspiring poetic force ("ewiger Born der Lieder"; Mackay 1911, 1: 220) - today we might call it writer's block - can soon be overcome. However, these ingredients, together with introspection and plenty of alcohol, provide an ideal preparation for a further development of the motif of the 
double. And indeed, in the poem "Der Zecher" [The Drinker], the narrating figure has a vision of himself, by night, in the mirror:

Und von geheimer Angst getrieben,

Tritt näher er an ihn heran,

$\mathrm{Zu}$ sehen, was diese Nacht geschrieben

Auf seine Züge haben kann. (Mackay 1911, 1: 156)

After this approach, worthy of Oscar Wilde's Dorian Gray, the drinker speaks to the mirror:

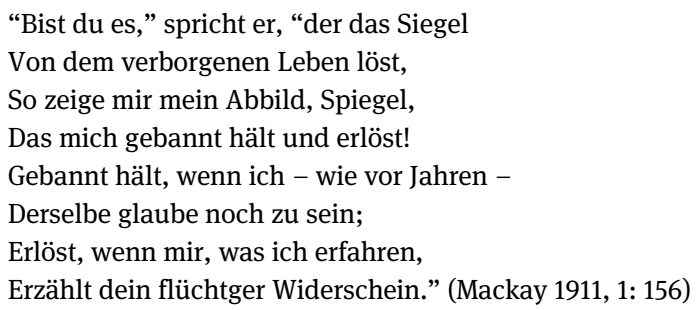

Similar scenarios and encounters can be found in Chamisso's poem "Die Erscheinung" [The Apparition], published in 1828, or in Lenau's "Der einsame Trinker" [The Lonely Drunkard] (1838). Mackay's protagonist keeps staring at his features, as if they were a stranger's face, unrecognizable to himself, which provokes an uncanny situation - in a truly Freudian sense:

Verwischt war, wie er einst gewesen,

Und ausgelöscht, was einst er war,

Er sah sich - lebend selbst verwesen,

Und sterben, was noch lebend war! (Mackay 1911, 1: 156)

The picture of Dorian Gray registers and reveals the sins of the past; the mirror has a similar function. Following the logic of Poe's and Wilde's narratives, the protagonist's reaction is also predictable: he destroys, of course, the mirror, and with it the treacherous image ("falsches Widerbild"; Mackay 1911, 1: 158) that prevents him from remaining the man he used to be.

"Wandlungen" [Alterations] presents another meeting with a ghastly double, again by night. The narrating self perceives another version of himself on a hill. A first impression of not identity but mere similarity has to be corrected: "Ich war es doch! ... Und ich erschauerte / Und wandte mich hinweg von jenem Bild" (Mackay 1911, 2: 20). Building up a Hoffmannesque tension, Mackay exploits the associations which the motif of the pale, menacing doppelgänger had acquired since the dark side of literary romanticism had manifested it- 
self. ${ }^{11}$ In this case, and unlike Egon Schiele's painting Selbstseher II (1911), the self-seer only has a vision of himself as a young man: "Ich sah mich selbst, wie ich vor Jahren war, / Als noch die erste Hoffnung mich durchbebte / - Die erste auch, die welkte von so vielen -" (1911, 2: 20).

Wilhelm Raabe, Mackay's contemporary and representative of German poetic realism, had already used the juxtaposition of a former self as a writing technique in the opening lines of his novel Die Chronik der Sperlingsgasse [Chronicle of Sparrow Alley] (Raabe 1997, first published 1856). Even in his naturalistic prose, Mackay would raise the problem of unfulfilled wishes and identity. His narrative "Herkulische Tändeleien: Die Geschichte einer Flucht” [Herculean Dalliances: The Story of an Escape] (1904) is the story of Karl W. Ettermann, whose unhappy marriage with the pretty, rich daughter of a factory-owner, and isolation in the town's established high society due to his unconventional social reform initiatives, cause a desire for breaking free and leaving it all behind. A look in the mirror confirms that what he feels and sees in himself is the result of having lived a wrong life:

Ihn grauste. Der ihn nie auch nur einen Augenblick in all diesen Jahren verlassen: der Gedanke, eines Tages wieder hinauszugehen in s e i n Leben, stand plötzlich vor ihm wie eine nicht mehr zu bändigende Macht und gewann Gewalt über ihn. Er mußte fort. Er wollte fort. (Mackay 1911, 6: 230)

Confronted with the memories of his active and adventurous past as a traveller, he carefully plans an escape into a new identity. After faking his own death by drowning in Lake Constance, his body obviously cannot be found because he was already on his way to Australia:

In Zürich machte er die verschiedensten Einkäufe: zunächst im Anglo-Americain am Bahnhof Anzüge und Wäsche, [...]. Als er am Abend einen Gang am Kai machte, glattrasiert und völlig frisch, war er wieder der wohlhabende und elegante Reisende, der zu seinem Vergnügen von Ort zu Ort reist. Er nannte sich für diesen Tag Charles D. Macintyre und sprach nur Englisch. Und am nächsten Morgen [...] las er im Café Riche in den schweizer und deutschen Blättern mit Befriedigung die Nachricht von seinem Tode. (Mackay 1911, 6: 246).

The protagonist's flight from an unsatisfactory German to a seemingly Scottish identity does not surprise us if we consider the author's biography. However, Mackay was not as proficient in English as one might assume. In his introduction to Dear Tucker: The Letters from John Henry Mackay to Benjamin R. Tucker, Hubert Kennedy admits:

11 In Mackay’s poem “Erscheinung” [Apparition] (1911, 2: 43-45), the fear of a terrible vision ("Bild des Schreckens") reaches its peak. 
While I have occasionally corrected misspellings I have made no attempt to "correct" his grammar, which in word order and especially in punctuation often follows German rather than English norms. Mackay also had difficulty selecting the right English translation for a German word if more than one choice was possible. For example the German word "wenn" can mean "when" or "if." The result was that he often wrote "when" but meant "if." Similarly, he sometimes wrote "become" for "receive" and "from" for "of." (Kennedy 2002, 10)

But then again, changing identities is easier for fictional literary characters or on the Internet than in real life. Nevertheless, Mackay translated English poems into German, and, during the years from 1895 to 1922, issued a series of eight propaganda pamphlets in German, mostly his own translations of articles by his anarchist friend Tucker.

\section{The loss of Heimat and alienation in poems excluded from Mackay's 1911 anthology}

In his preface to his collected works of 1911, Mackay justifies the exclusion of his tragedy Anna Hermsdorff (1885), which, in his opinion, was more amusing than moving. Furthermore, his first studies in prose ("schlecht") and several juvenile poems ("Jugend-Sünden") were omitted, as well as some of his translations of English and American poetry that, according to him, deserved a better translator than he had been. However, in his first volume of poetry, Dichtungen (1886), we can find further traces of a long-lasting identity crisis, but also evidence for Mackay's identification with Scotland. In a poem written on his departure from Edinburgh, dated 28 September 1884, the author confesses:

Was liegt da hinter mir? Nicht nur ein Land, Wie andre Länder, Menschen gleich den andern, Nein: unaussprechlich mehr! Der Heimat Strand, Den ich verlasse jetzt, um fern zu wandern. (Mackay 1886, 22)

The young poet revisits this theme in the first lines of "Stimmungen," which were not included in the edition of 1911: "Mir ist's als könnt' ich's wiederfinden, / Mein Heimathaus, das ich verlor [...]" (Mackay 1886, 22). In another poem excluded from the anthology, he associates sickness and death with his homeless existence (“dem Heimatlosen"; Mackay 1886, 63), motifs that pervade his early productions. "Ein einsames Sterben ..." demonstrates the introspective attitude of a Romantic literary heritage: "In dumpfes Grübeln sank er nun. Sich selbst / Wollt' er erkennen, um aus seines Innern, / Bisherigem Zwiespalt Schöpferkraft zu saugen" (Mackay 1886, 189). This attitude reveals also a narcissistic approach and persists 
in Mackays next publication, Fortgang [Continuation] (the first sequel to his Dichtungen): "Du hast dich in dein eigenes Bild vertieft" (Mackay 1888, 64). The recurring themes and motives seem to be the bars of a cage, preventing any escape from the threatening thoughts and menacing shadows that bear the germs of sin, as in "Gesang der Einsamen" [Song of the Lonesome]:

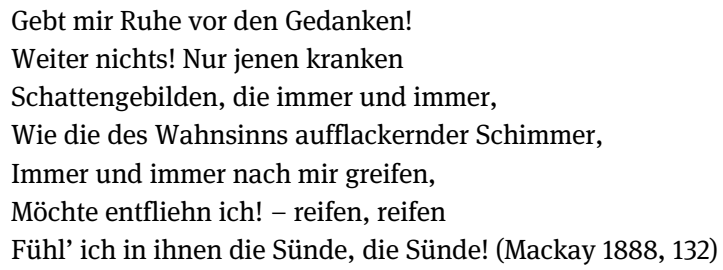

Unsurprisingly, feelings of remorse are also experienced as a haunting and take shape in the poem "Die Reue" [Remorse], where the sin, or rather a nameless deed ("That"), remains unforgiven. Like an Erinys, the personification of remorse follows the sinner wherever he seeks refuge. The imagery used reminds us of Peter Schlemihl's shadow in Chamisso's amazing story: ${ }^{12}$

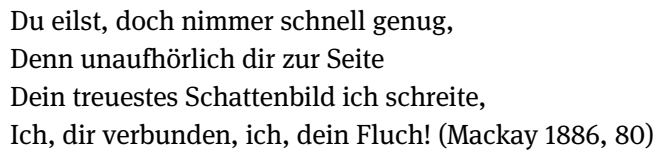

It would certainly be intriguing to speculate about the nature of the committed sin or about Mackay's criteria for the selection in the 1911 edition of his works. Allusions in some of the excluded poems seem to be explicit enough to suspect selfcensorship due to their homoerotic content. For example, in "Nächte der Liebe" [Nights of Love], he mentions the "Schöne Lebens-Lust der Griechen-Tage" (Mackay 1888, 71), aware of it being a "frevelnd-unsittlicher Wahn" (Mackay $1888,72)$ in public opinion. Even before his long love poem "Helene" (1888), which Mackay "heterosexualized" by changing "the sex of one of the partners in the relationship" (Kennedy 2002, 31), the author had used this strategy in "In der Fremde” [In a Strange Place]:

12 Adelbert von Chamisso, Peter Schlemihls wundersame Geschichte [The Amazing History of Peter Schlemihl], written in 1813, was published in 1814. Annette von Droste-Hülshoff, whom Mackay deeply admired (cf. Mackay 1888, 93), used the mirror as a door to perception of a second self in her poems "Das Fräulein von Rodenschild" (1841), "Das Spiegelbild” (1842), and "Doppeltgänger” (1844). 
Vielleicht hast du mich längst vergessen.

Um andern Frauen dich zu schenken,

Um andre Bahnen zu durchmessen.

Und während ich hier ruhlos ringe,

Liegst du an eines Weibes Brüsten,

Und während ich mich dar dir bringe,

Schwelgst du in fremden, eklen Lüsten. (Mackay 1888, 95)

Despite this transposition of sexes, "In der Fremde" was not included in his collected works either. However, its title adds to the impression and insights that we have already gained from other poems of and into an alienated, torn, and tortured poetical self which can be, but does not necessarily have to be, identified with that of the author.

\section{Conclusions}

In my analysis, which includes aspects of travel, translation, and the translingual borrowing of literary, aesthetic, and rhetorical structures and strategies, the focus has clearly been on Mackay's literary fantasies of fragmentation. These appear frequently in literary romanticism and modernism, and, as I have stated elsewhere (Bär 2011, 2015), are common in authors who aim at expressing strangeness in a heterosocial context.

After the publication of Kinder des Hochlands in 1885, some of the German literary critics assumed that Mackay, as a Scotsman by birth, had written his poetry in a foreign language ("als geborener Schotte in einer fremden Sprache dichtet"; Karl Bleibtreu). ${ }^{13}$ This was certainly considered an asset, contributing to an overall favourable reception of his work which earned him comparisons with Tennyson's Enoch Arden and Scott's Lord of the Isles. Still, in his entry on Mackay in the

13 Mackay combined excerpts of this and several other favourable reviews of his previous books in the edition of his Dichtungen (1886, n. pag.), thus perpetuating this wrong assumption which was spread by "Karl Bleibtreu im Deutschen Tageblatt vom 6. März 1885" and by the "Neue Illustrierte Zeitung, Nr. 33, 1885." The information provided by "Die Gesellschaft, Nr. 45, 1885" is slightly more precise, although reminiscencing on the topoi introduced by Ossian: "Auch das ist ein Werk der Kunst und kein Werk der Mode. Der hochbegabte jugendliche Dichter ist ein geborener Schottländer, und wenn auch seit frühesten Jahren in Deutschland erzogen und gebildet, so wallt doch sein heißes Schottenblut in leidenschaftlicher Liebe auf, gedenkt er der fernen Bergheimath, ihrer schauerlich grandiosen Szenerie, ihres phantastischen Himmels, ihrer wildwüchsigen, wetterharten, stark empfindenden Menschen.” 
Führer durch die Moderne Literatur, Mühsam emphasizes the extraordinary fact that a Scotsman by birth writes only in German.

Both John Henry Mackay and Houston Stewart Chamberlain endeavoured to find and define their identity and home (in the sense of Heimat) through literature. Chamberlain developed a tendency towards repressing aspects of British and French civilization he had acquired through his upbringing and education, in order to supplant them with German "Kultur."14 This earned him the recognition of the influential ideologue of the Nazi Party Alfred Rosenberg, who called him the "Seher des Dritten Reiches" [Visionary of the Third Reich]. ${ }^{15}$ Contrary to Chamberlain's approach, which culminated in a Wagnerian epiphany, Britishness and Scottishness are, in Mackay's writing, elements of a positive otherness in a German environment. Longing for a childhood in Scotland that was interrupted, revisited (travel), and poetically reconstructed in Kinder des Hochlands, the author created memories he did not have. While Mackay was looking for his roots, Chamberlain cut them off at an early age: "ich bin so gänzlich unenglisch geworden, daß schon der bloße Gedanke an England und an Engländer mich unglücklich macht” (from a letter to his aunt, Interlaken, 21 September 1876; Chamberlain [1919, 59]).

While Chamberlain denounced and rejected Englishness, and even the English language, ${ }^{16}$ in favour of a racially founded pan-Germanic ideal of purity which fed into the völkisch anti-Semitism of Nazi racial policy, Mackay found his political vocation in London, observing the German exiles interact with their host country and meeting protagonists of the socialist-anarchist movement such as Gertrud Guillaume-Schack, Otto Rinke, Peter Kropotkin, William Morris, and Charlotte Wilson. Mackay's otherness turned into a creative force and became a dominant theme in his poetical and narrative writing. For Chamberlain, drawing on multilingualism and cultural hybridity (British, French, German) was unacceptable due to his concept of racial superiority.

14 Compare the diverging concepts of "culture” and "civilization” in Elias’s Über den Prozeß der Zivilisation.

15 Cf. Grundmann (1904).

16 Chamberlain claims: "Die englische Sprache ist nämlich nicht allein eine gedrungene, harte, seelenlose, rein praktische Geschäftssprache, vielmehr ist sie außerdem eine Sprache der Ahnungen, der nebelhaft grenzunsicheren Gefühle: die englische Poesie bezeugt das alles tausendfach, wie namentlich ein Blick auf die Gruppe um Shelley dartut” $(1919,177)$. 


\section{Works cited}

Bär, Gerald. "Fantasies of Fragmentation in Conrad, Kafka and Pessoa: Literary Strategies to Express Strangeness in a Hetero-Social Context." Amaltea: Revista de mitocrítica 3 (2011): $1-21$.

Bär, Gerald. "Case Studies of Literary Multilingualism: Expressing Alterity in a Self-Referential Recourse to the Motif of the Double." Paradoxes du plurilinguisme littéraire 1900: Réflexions théoriques et études de cas. Ed. Britta Benert. Brussels: Lang, 2015. Nouvelle poétique comparatiste. 171-193.

Bahr, Hermann. Der Antisemitismus: Ein internationales Interview. Berlin: Fischer, 1894.

Chamberlain, Houston Stewart. Die Grundlagen des neunzehnten Jahrhunderts. 2 vols. Munich: Bruckmann, 1899.

Chamberlain, Houston Stewart, The Foundations of the Nineteenth Century. Trans. John Lees. Intro. Lord Redesdale. London and New York: Lane, 1911.

Gobineau, Arthur de. Essai sur l'inégalité des races humaines. Paris: Didot, 1853-1855.

Grundmann, Walter. Review of H. Mayer, Houston Stewart Chamberlain als völkischer Denker, 1939, and Hermann Wolfgang Beyer, Houston Stewart Chamberlain und die innere Erneuerung des Christentums, 1939. Theologische Literaturzeitung: Monatsschrift für das gesamte Gebiet der Theologie und Religionswissenschaft 7-8 (1940): 210-211.

Hertz, Friedrich. Rasse und Kultur: Eine kritische Untersuchung der Rassentheorien. Leipzig: Kröner, 1915.

Holz, Arno. Socialaristokraten. Rudolstadt and Leipzig: Mänicke \& Jahn, 1896.

Kennedy, Hubert. Reading John Henry Mackay: Selected Essays. San Francisco: Peremptory Publications, 2002.

Mackay, John Henry. Dichtungen von John Henry Mackay. Munich and Leipzig: Heinrichs, 1886.

Mackay, John Henry. Fortgang: Von John Henry Mackay: Der “Dichtungen” erste Folge. Großenhain and Leipzig: Baumert \& Ronge, 1888.

Mackay, John Henry. The Anarchists: A Picture of Civilization at the Close of the Nineteenth Century. Trans. George Schumm. Boston: Tucker, 1891.

Mackay, John Henry. Gesammelte Werke. 8 vols. Treptow bei Berlin: Zack, 1911.

Mackay, John Henry. Abrechnung: Randbemerkungen zu Leben und Arbeit. 1932. Freiburg im Breisgau, 1978.

Mackay, John Henry. Dear Tucker: The Letters from John Henry Mackay to Benjamin R. Tucker. Ed. and trans. Hubert Kennedy. San Francisco: Peremptory Publications, 2002.

[Macpherson, James]. The Works of Ossian: Translated from the Galic language by James Macpherson: The third edition: To which is subjoined a critical dissertation on the poems of Ossian: By Hugh Blair. London: Printed for T. Becket and P. A. Dehondt, 1765.

“Maritime Monday - Fish Killing Fishermen!" Many Years Ago: Genealogy Writing about My Ancestors. 27 November 2012. https://sbaird1.wordpress.com/category/mctavish/duncanmctavish/ (25 February 2019).

Raabe, Wilhelm. Die Chronik der Sperlingsgasse. 1856. Hameln: Niemeyer, 1997.

Ritchie, J. M. “John Henry Mackay’s London.” New German Studies 8 (1980): 203-220.

Ritchie, J. M. "Das Bild Londons in dem Romanwerk des deutschen Anarchisten John Henry Mackay." Rom - Paris - London: Erfahrung und Selbsterfahrung deutscher Schriftsteller und Künstler in den fremden Metropolen: Ein Symposion. Ed. Conrad Wiedemann. Stuttgart: Metzler, 1988. 635-647. 
Scott, Walter. The Lay of the Last Minstrel: A Poem. London: Printed for Longman, Hurst, Rees, and Orme, Paternoster-Row, and A. Constable and Co., Edinburgh, by James Ballantyne, Edinburgh, 1805.

Spitzer, Leo. Anti-Chamberlain: Betrachtungen eines Linguisten über Houston Stewart Chamberlains "Kriegsaufsätze" und die Sprachbewertung im allgemeinen. Leipzig: Reisland, 1918.

“ThomasGOLDIE.” Mull Genealogy. n.d. http://www.mullgenealogy.co.uk/MullSearch.Asp?indv_no=51762 (31 January 2017).

Gerald Bär is currently assistant professor at the Universidade Aberta of Portugal, where he lectures in German and Comparative Literature. He is a senior researcher at the Research Centre for Communication and Culture at Univ. Católica Portuguesa. Publications (selection) at https://orcid.org/0000-0002-3948-2153. 
